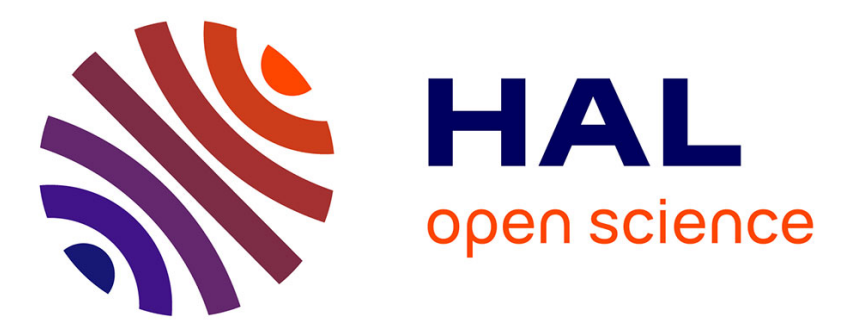

\title{
Bovine embryo cryopreservation in a chemically defined medium
}

\author{
A. Østergaard, L. Gavin-Plagne, M. Guedes Teixeira, S. Buff, T. Joly
}

\section{To cite this version:}

A. Østergaard, L. Gavin-Plagne, M. Guedes Teixeira, S. Buff, T. Joly. Bovine embryo cryopreservation in a chemically defined medium. Annual Conference of the International Embryo Technology Society, Jan 2020, New York, United States. Reproduction, Fertility and Development, 32 (2), pp.142, 2020, 10.1071/RDv32n2Ab32 . hal-02450394

\section{HAL Id: hal-02450394 \\ https://hal-vetagro-sup.archives-ouvertes.fr/hal-02450394}

Submitted on 22 Jan 2020

HAL is a multi-disciplinary open access archive for the deposit and dissemination of scientific research documents, whether they are published or not. The documents may come from teaching and research institutions in France or abroad, or from public or private research centers.
L'archive ouverte pluridisciplinaire HAL, est destinée au dépôt et à la diffusion de documents scientifiques de niveau recherche, publiés ou non, émanant des établissements d'enseignement et de recherche français ou étrangers, des laboratoires publics ou privés. 


\section{Bovine embryo cryopreservation in a chemically defined medium}

A. Østergaard ${ }^{1,2}$, L. Gavin-Plagne ${ }^{1,3}$, M. Guedes Teixeira ${ }^{1}$, S. Buff ${ }^{1}$, T. Joly ${ }^{1,4}$

${ }^{1}$ UPSP ICE, VetAgro Sup, Marcy L'Etoile, France

${ }^{2}$ Gènes Diffusion, Douai, France

${ }^{3}$ IMV Technologies, L'Aigle, France

4ISARA Lyon, France

Ti:33621757704 \ ostergaard@genepro-inc.com

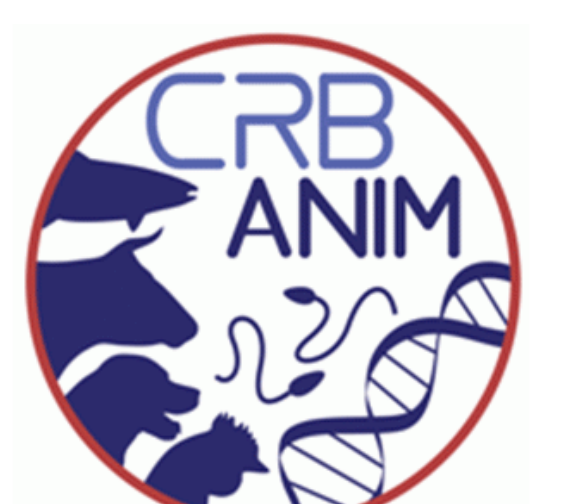

A VetAgro Sup

iscra

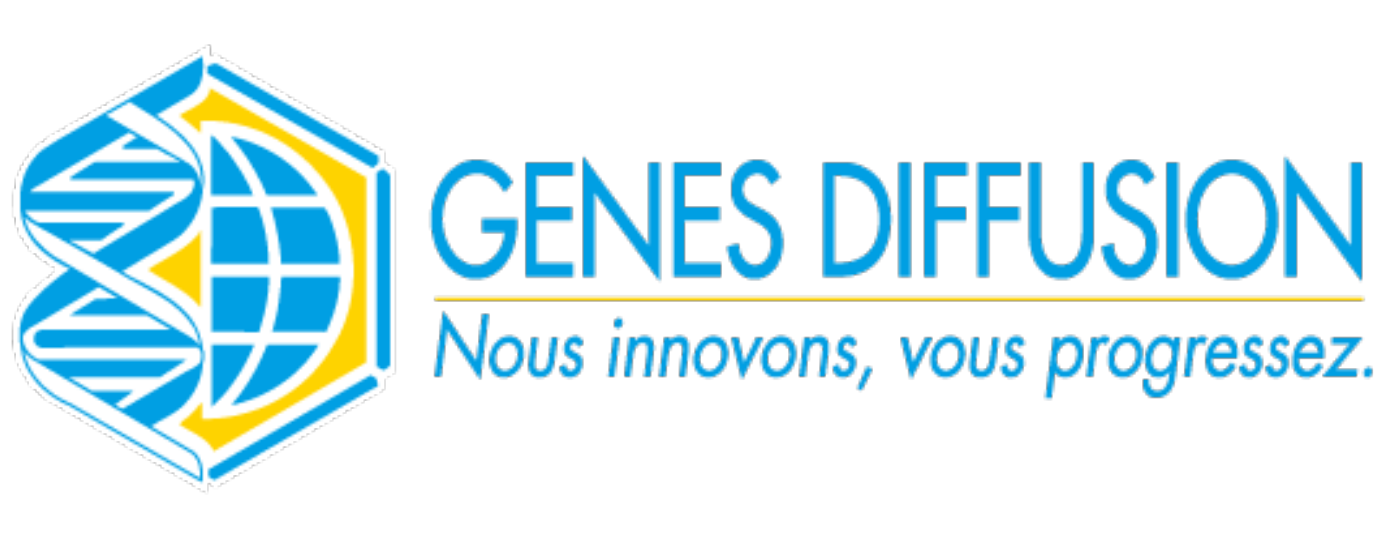

\section{CONTEXT AND OBJeCTIVE}

Embryo cryopreservation media often contain an animal-derived component, such as bovine serum albumin (BSA) or fetal calf serum. However, the industry is faced with the issue of composition variability between batches and, most importantly, the risk of pathogen transmission. The aim of this study was to compare the effectiveness of two embryo cryopreservation ethylene glycol-based media: IMV's freezing medium with BSA (IMV Technologies) and a chemically defined medium containing STEMALPHA.CRYO3, called CRYO3 (Ref 5617, Stem Alpha). CRYO3 is produced according to EU good manufacturing practice, ensuring the composition and quality of the product.

Materials And Methods

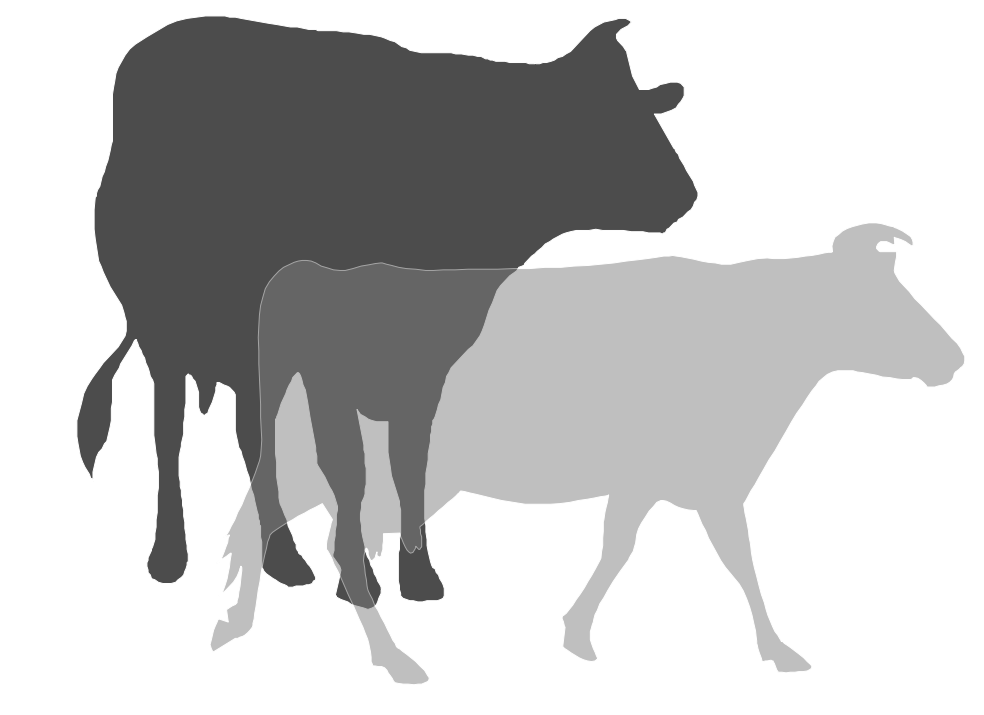

10 commercial herds

60 donors

246 frozen embryos

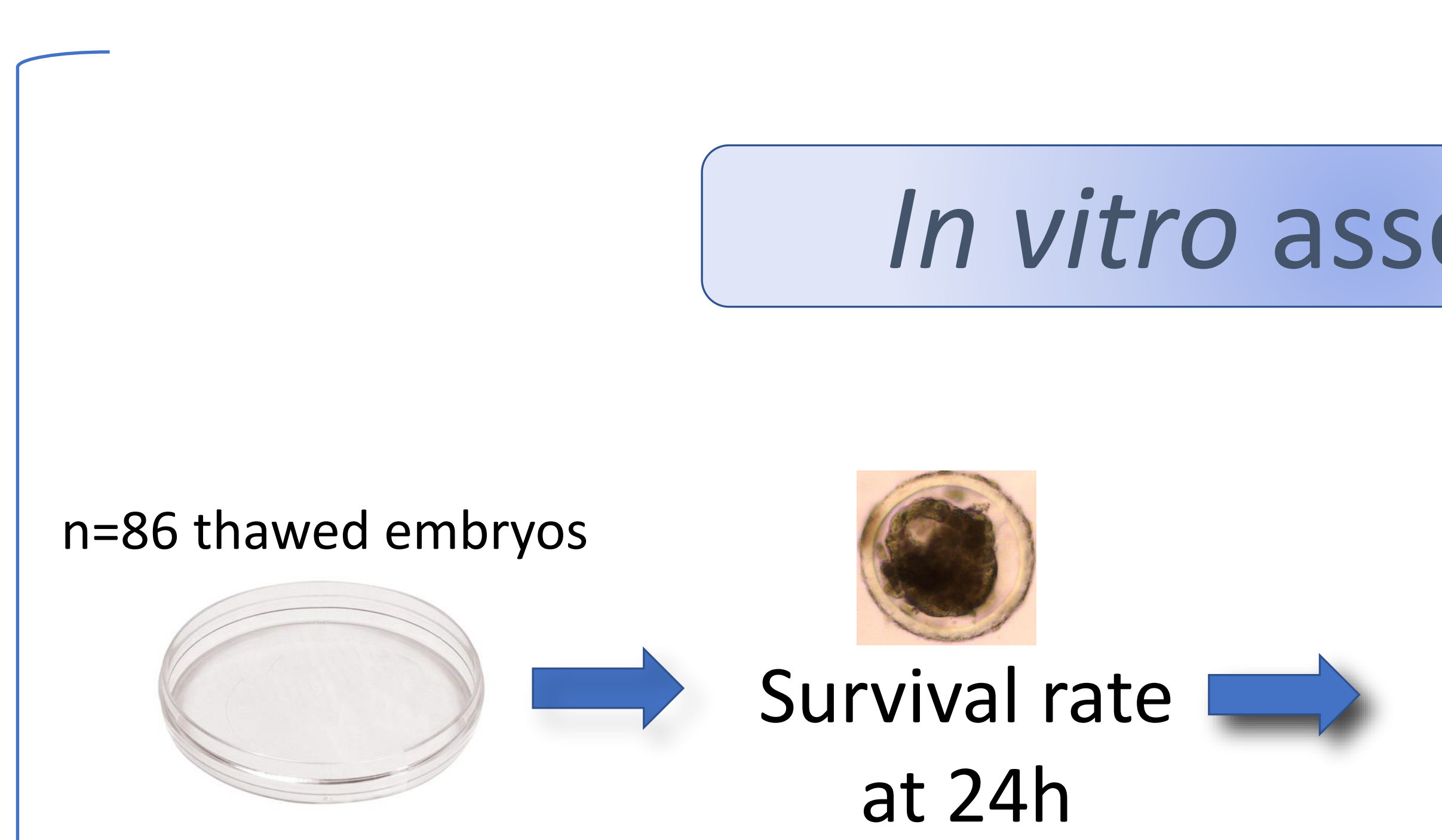

\section{In vitro assessment}

(1:1 mixture of RPMI, Dulbecco's modified Eagle's medium, and Ham's F10 Incubated at $38.5^{\circ} \mathrm{C}$ with $5 \% \mathrm{CO} 2$

Monitored every 24 hours for 72 hours

\section{In vivo assessment}

CRYO3 synthetic freezing medium (20\% CRYO3 ref5617 in DBPS)

$\mathrm{n}=123$ recipients (1 thawed embryo/cow)
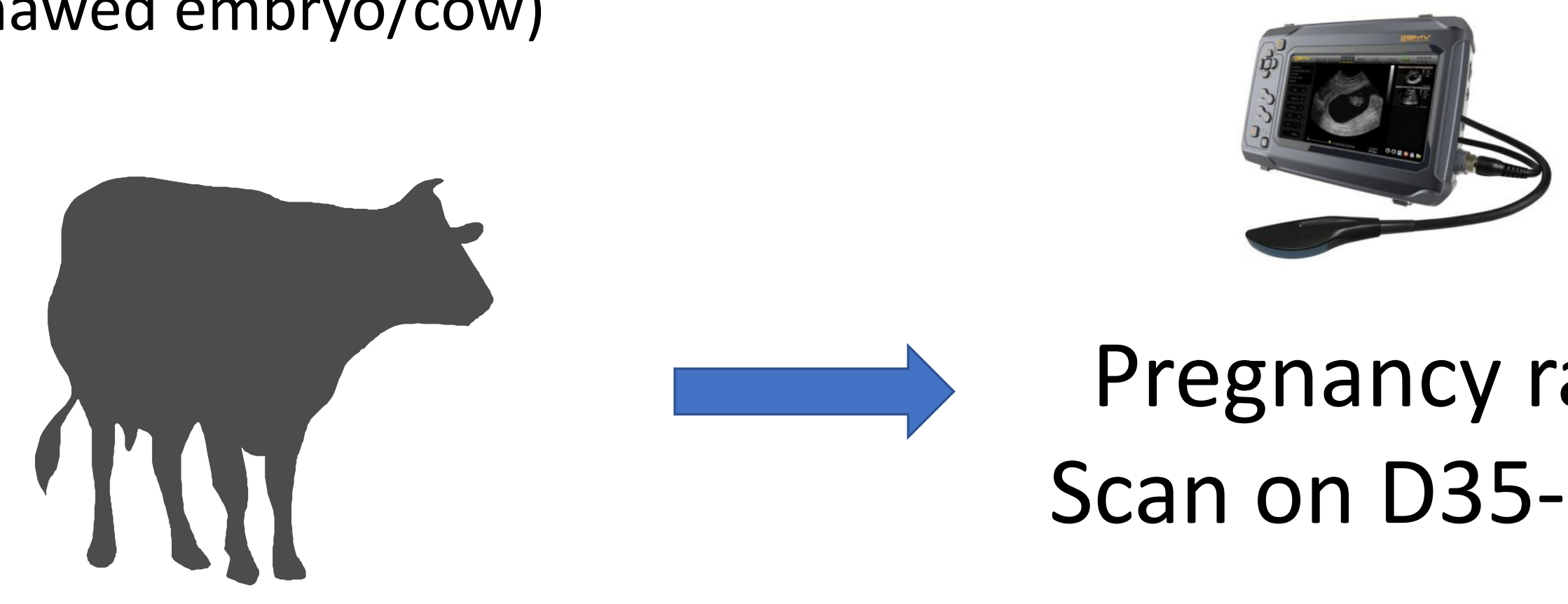

Pregnancy rate Scan on D35-D50

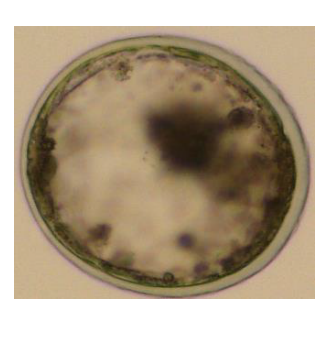

Epansion rate

at $48 \mathrm{~h}$

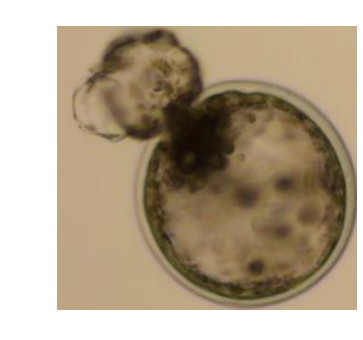

Hatching rate at $72 \mathrm{~h}$

Statistics: Chi-2 squared with Yate's correction

\section{RESULTS}

\section{In vitro assessment}

\begin{tabular}{c|c|c|c|c} 
& $\begin{array}{c}\text { Embryos } \\
\text { thawed }\end{array}$ & $\begin{array}{c}\text { Survival } \\
\text { rate }(24 \mathrm{~h})\end{array}$ & $\begin{array}{c}\text { Expansion } \\
\text { rate }(48 \mathrm{~h})\end{array}$ & $\begin{array}{c}\text { Hatching } \\
\text { rate }(72 \mathrm{~h})\end{array}$ \\
\hline BSA & 44 & $\begin{array}{c}50 \%^{\mathrm{a}} \\
(\mathrm{n}=22)\end{array}$ & $\begin{array}{c}14 \%^{\mathrm{c}} \\
(\mathrm{n}=6)\end{array}$ & $\begin{array}{c}18 \%^{\mathrm{c}} \\
(\mathrm{n}=8)\end{array}$ \\
\hline CRYO3 & 42 & $\begin{array}{c}74 \%^{\mathrm{b}} \\
(\mathrm{n}=31)\end{array}$ & $\begin{array}{c}38 \%^{\mathrm{d}} \\
(\mathrm{n}=16)\end{array}$ & $\begin{array}{c}40 \%^{\mathrm{d}} \\
(\mathrm{n}=17)\end{array}$
\end{tabular}

Within columns, superscript with different letters are significantly different $(p<0.05)$
In vivo assessment

\begin{tabular}{c|c|c|c|} 
& Recipients & $\begin{array}{c}\text { Pregnancy } \\
\text { rate }\end{array}$ & $\begin{array}{c}\text { Calving } \\
\text { rate }\end{array}$ \\
\hline BSA & 64 & $\begin{array}{c}63 \%^{n s} \\
(n=40)\end{array}$ & $\begin{array}{c}55 \%{ }^{n s} \\
(n=35)\end{array}$ \\
\hline CRYO3 & 59 & $\begin{array}{c}73 \%{ }^{n s} \\
(n=43)\end{array}$ & $\begin{array}{c}64 \%{ }^{n s} \\
(n=38)\end{array}$
\end{tabular}

ns= nonsignificant

The trial was conducted with different Al teams and in 10 commercial herds, thus adding robustness to the data.

\section{CONCLUSION}

This study has shown that 20\% CRYO3 in DPBS can replace BSA in an ethylene glycol cryopreservation medium for in vivo-produced bovine embryos. Therefore, this product eliminates a sanitary risk in embryo commerce, which is a concern in an international context. 